\title{
ECONOMIC ACTIVITY IN CONTEXT OF REGIONS, EDUCATION LEVEL, AGE GROUP AND GENDER: CASE OF LATVIA ${ }^{1}$
}

\author{
BIRUTA SLOKA \\ KATE ČIPĀNE
}

\begin{abstract}
In the National Development Plan of Latvia 2014-2020 it is written that society is aware that social, regional and opportunity inequalities can be reduced by a high overall employment rate in which everyone seeks for productivity. High employment rate is important not only for decreasing inequalities in country, but also for promoting economic growth. There have always been employment challenges in Latvia that are complex and insufficiently researched in academic research. The aim of the study is to analyse economic activity in Latvia by regions, education level, age group and gender. Research methods used in preparation of the article: scientific publication and previous conducted research results analysis, analysis of Labour Force Survey results (in 2014-2017) which are compared with the results of other European Union and OECD countries. Survey results are analysed using indicators of descriptive statistics (indicators of central tendency or location - arithmetic mean, mode, median), indicators of variability (indicators of dispersion - range, standard deviation and standard error of mean), cross-tabulations by regions in Latvia, by level of education, by age group, by gender and analysis of variance - ANOVA are used. The results of analysis indicated that the highest unemployment rate is in Latgale region and the higher the level of education, the less likely it is to be unemployed in Latvia.
\end{abstract}

Keywords: Latvia, economic activity, employment, employees, labour force, regional development, unemployment

JEL code: J24; M59; R51

\section{INTRODUCTION}

The analysis of economic activity and employment is essential for a country and it is also an important question whether employment is growing or decreasing. According to the National Development Plan of Latvia 2014-2020 society is aware that social, regional and opportunity inequalities can be reduced by high overall employment rate in which everyone seeks for productivity (NDPL 2014-

1 The research was supported by the National Research Programme "Latvian Heritage and Future Challenges for the Sustainability of the State" project "Challenges for the Latvian State and Society and the Solutions in International Context (interframe-lv)”. 
2020). Taking into account all mentioned before, the purpose of the study is to analyse economic activity in Latvia by regions, education level, age group, gender and household composition.

The tasks of the study:

1) to analyse theoretical background of economic activity in context of regional development, level of education, age group, gender and household composition;

2) to analyse existing research of economic activity in the regions in EU; and

3) to analyse problems of economic activity by regions of Latvia, by level of education, by age group, by gender, by household composition.

Research methods used in preparation of the paper: scientific publication and previous conducted research results analysis, analysis of Labour Force Survey results (in 2014-2017) which are compared with the results of other European Union and OECD countries. Survey results are analysed using indicators of descriptive statistics (indicators of central tendency or location - arithmetic mean, mode, median), indicators of variability (indicators of dispersion - range, standard deviation and standard error of mean), cross-tabulations by regions in Latvia, by level of education, by age group, by gender and analysis of variance ANOVA are used.

\section{EMPLOYMENT DIFFERENCES IN LATVIA: THEORETICAL FRAMEWORK}

Business and economic theory both hypothesise that employment is crucial for successful development of the country, this is also proven by OECD, Eurostat and other institutions that collect data about the most important measures of the country. Often differences in employment occurs in certain regions of the country or age-groups, level of education or gender. Researchers from Switzerland (Muresan, et al., 2019) have indicated key factors for sustainable rural development and economic activity in the region involving as much as possible inhabitants.

Gender differences in employment and work results are on research agenda for many researchers world-wide including aspects of professional growth (Wang, Long, 2019) Gender differences in employment have been researched in Nepal and the study revealed that despite the level of education females from rural areas have fewer opportunities to find regular work and they face significant wage discrimination than males and females from urban areas (Yamamoto, et al., 2019). Forsyth and his colleagues (Forsyth, et al., 2019) were researching opportunities and barriers for females that study and are employed in sport and revealed that there is gender discrimination in sport, however self-confidence and self-belief could be important factor for success.

One of the main aspects for female employment is education and study based on women surveyed in 139 countries (Bussemakers, et al., 2017) indicated that 
women employment in countries with conservative gender norms is lower than in liberal countries. Research about vocational education and employment (Forster, Bol, 2018) revealed that benefits young people receive after having vocational education disappear later in the career and decrease employability.

Some studies have revealed that there are differences between in employment by age groups, for example, Wandner and his colleagues (Wandner, et al., 2018) have indicated that there are serious problems for older workers to be employed in the U.S., because the public workforce system is not adapted to serve older workers as they need more in-person, one-on-one services including consulting and placement services. In developed countries it is paid a lot of attention of involvement of elderly in several social activities and to those aspects are devoted many researches (Cho, Kim, 2019) including also subjective aspects.

Employment has been researched also in other aspects, for example, minimum wage in Germany was introduced in 2015. And Holtemöller and Pohle have indicated that there is robust negative effect of minimum wage on a marginal employment and robust positive effect on regular employment, and low-wage employees who are still employed are better off at the expense of those who have lost their jobs due to the minimum wage. Researchers (Holtemöller, Pohle, 2019) also have pointed out that this case is an example which shows that regional differences are very important and should be considered in the implementation process of new minimum wage regulations.

Study in US (Dogru, et al., 2020) was researching how sharing economy company Airbnb affect employment in the tourism, hospitality and leisure industries and revealed that employment in the hotel sector increases with increased Airbnb listings although prior studies showed that Airbnb has negative effect on hotels' financial performance measures.

Several studies have been devoted to researching relationship between employment and health related issues. Research results in China (Zhu, et al., 2019) have indicated that there is an evidence that economic activity - such as foreign trade, economic growth and industrial structure increase smog concentration in China. Another study in 16 European Union countries (Niedzwiedz, et al., 2019) was exploring regional employment and individual worklessness and the health of the working-age population and revealed that higher levels of employment in the regional labour market may be beneficial for the health of the local population. But unemployment has been associated with chronic stress what can cause health problems. Researcher Sumner and his colleagues (Sumner, et al., 2019) revealed that unemployment really is associated with increases in one marker of peripheral inflammation, but this health protection is not conferred to those in precarious employment. 


\section{EMPIRICAL RESEARCH RESULTS}

The EU Labour Force Survey (EU-LFS) is the largest European household sample survey. The EU-LFS survey provide quarterly and annual data in line with Eurostat methodology in all European Union countries, three EFTA countries (Iceland, Norway and Switzerland), and four EU candidate countries (Montenegro, North Macedonia, Serbia and Turkey).

One of the main study objects of the EU-LFS is monthly harmonised unemployment rate - one of Eurostat's key short-term indicators. Sample size of EU-LFS in Republic of Latvia in 2017 was 42041 persons.

It is important that anonymised data sets are available in SPSS files for more detailed statistical data analysis - by statistical regions, by territories (cities or rural areas), by household size and by other indicators.

\section{UNEMPLOYMENT IN THE REGIONS IN EU}

The statistics show that unemployment rate in Baltic countries is lower than average in EU in 2019. The highest unemployment is in Latvia, followed by Lithuania. At the same time unemployment rate in Estonia is the lowest what means that only around 4 percent of populations do not have work.

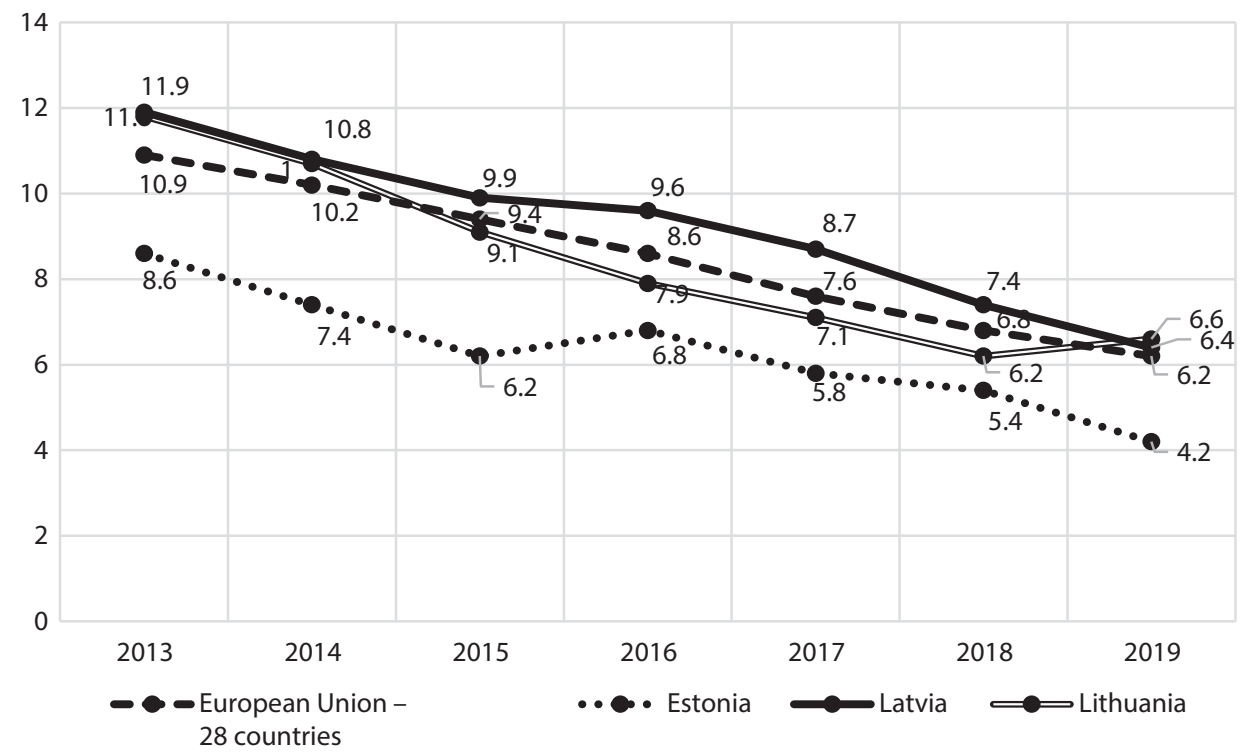

Source: Authors construction based on EU-LFS

Fig. 1. Total unemployment rate in Baltic States and EU-28 in 2013-2019 (\%) 


\section{PROBLEMS AND CHALLENGES OF UNEMPLOYMENT: CASE OF LATVIA}

According to the administrative breakdown, there are 6 regions in Latvia: Riga, Pierīga, Vidzeme, Kurzeme, Zemgale and Latgale. In Figure 2 is revealed economic activity in regions of Latvia. Unemployment is very different in those regions indicating higher unemployment in some regions: in Vidzeme and especially in Latgale.

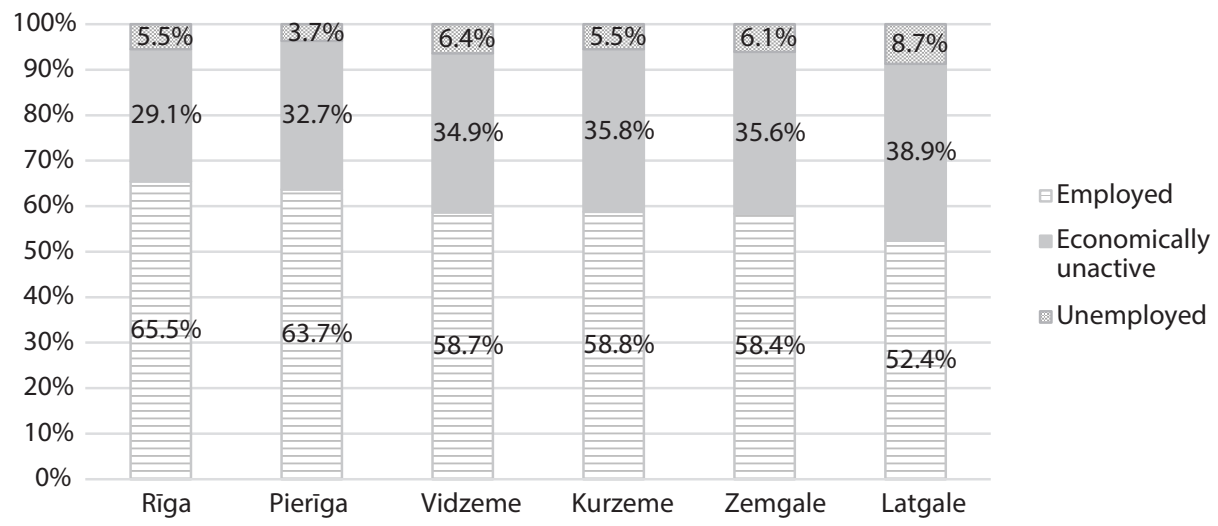

Source: Authors construction based on EU-LFS

Fig. 2. Economically active and inactive population in regions of Latvia in 2017 (\%)

Economic activity varies considerably between regions of Latvia. The highest unemployment is in Latgale region where also the total economically active population is the lowest and it differs by 10 percent compared to Riga region. As well this region has the most economically inactive people meaning that part of them live on benefits from country or possibly on the benefits of the black economy. Vidzeme and Zemgale region is in similar situation, but interesting that Kurzeme region and Riga region is on the same level of unemployment, but the Pieriga region has the lowest unemployment in the country driven by the migration of young families - to areas adjacent to the capital - away from city noise, but at the same time close to wider opportunities of studies and employment.

Table 1

Main results of analysis of variance (ANOVA) on economically active and inactive population in 2017 by education level in Latvia

\begin{tabular}{|l|c|r|r|r|r|}
\hline & Sum of Squares & \multicolumn{1}{c|}{ df } & Mean Square & \multicolumn{1}{c|}{ F } & \multicolumn{1}{c|}{ Sig. } \\
\hline Between Groups & 3176.987 & 4 & 794.247 & 1024.416 & 0.000 \\
Within Groups & 23600.649 & 30440 & 0.775 & & \\
Total & 26777.636 & 30444 & & & \\
\hline
\end{tabular}

Source: Authors' calculations based on EU-LFS data in 2017 
The data of Table 1 (results of ANOVA) indicate that there are differences in economic activity by education level in Latvia and they are statistically significant (sig. 0.000). Data included in Figure 3 describe interaction between education level and economic activity.

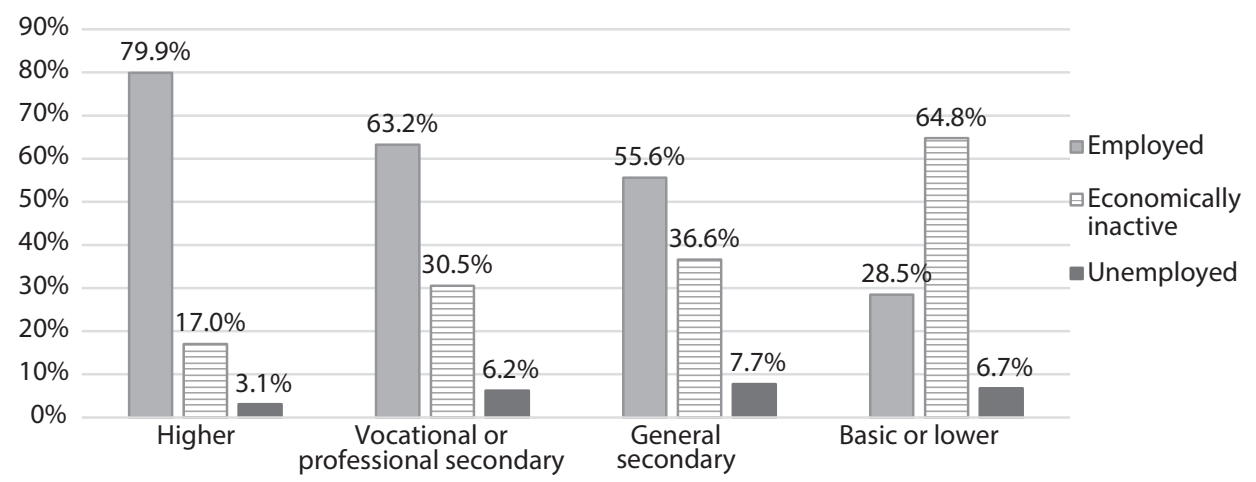

Source: Authors construction based on EU-LFS

Fig. 3. Economically active and inactive population by education level in Latvia in 2017 (\%)

Statistics shows that the higher the level of education, the less likely it is to be unemployed in Latvia and economic inactivity is highly prevalent among people with basic education or lower. But unemployment is the highest among them with the general secondary education, followed by those with basic education or lower. The analysis reveals that getting higher education can be a guarantee for the future to have a job and develop their further life with better living conditions and more opportunities for qualitative life.

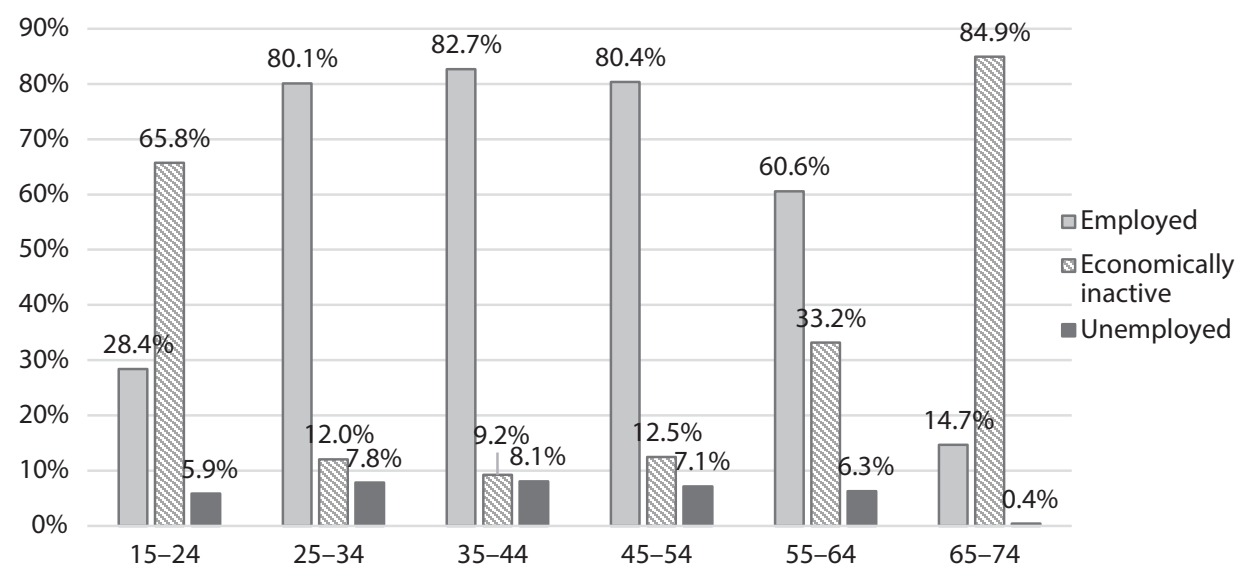

Source: Authors construction based on EU-LFS

Fig. 4. Economically active and inactive population by age-group in Latvia in 2017 (\%) 
The data of Figure 4 indicates that the most employed age group in Latvia is those between 35 to 44 years old, followed by 45-54 years old and 25-34 years old. Economic inactivity and unemployment in these three age groups are the smallest. People between 15 and 25 years old are mostly economically inactive as well as those who are in retirement - 65 to 74 years old. In many scientific publications in many countries is concluded that there are differences in economic activity by gender. To test this aspect, authors analysed results on economic activity by gender - main results of analysis are included in Table 2.

Table 2

Main statistical indicators of economic activity in 2017 by gender in Latvia

\begin{tabular}{|l|c|c|c|c|}
\hline \multicolumn{1}{|c|}{ Gender } & N & Mean & $\begin{array}{c}\text { Standard } \\
\text { Deviation }\end{array}$ & $\begin{array}{c}\text { Standard Error of } \\
\text { Mean }\end{array}$ \\
\hline Male & 13750 & 1.68 & 0.910 & 0.008 \\
\hline Female & 16695 & 1.81 & 0.956 & 0.007 \\
\hline
\end{tabular}

Source: Authors' calculations based on EU-LFS data in 2017

As the data of Table 2 indicates - the economic activity of male and female respondents are very alike with more differences in evaluations by female respondents - indicated by bigger standard deviation. To analyse deeper and be more precise in conclusions the t-test was used to test statistical hypotheses on differences of means on economic activity by female and male respondents on economic activity and inactivity - results are included in Table 3.

Table 3

Analysis of differences with t-test on economic activity in 2017 by gender in Latvia

\begin{tabular}{|l|c|c|c|c|c|c|c|}
\hline & \multicolumn{2}{|c|}{$\begin{array}{c}\text { Levene's Test } \\
\text { for Equality of } \\
\text { Variances }\end{array}$} & \multicolumn{6}{|c|}{ t-test for Equality of Means } \\
\cline { 2 - 8 } & F & Sig. & t & df & $\begin{array}{c}\text { Sig. } \\
\text { (2-tailed) }\end{array}$ & $\begin{array}{c}\text { Mean } \\
\text { Difference }\end{array}$ & $\begin{array}{r}\text { Std. Error } \\
\text { Difference }\end{array}$ \\
\cline { 2 - 8 } & 514.430 & 0.000 & -12.131 & 30443 & 0.000 & -0.131 & 0.011 \\
$\begin{array}{l}\text { Equal variances } \\
\text { assumed } \\
\begin{array}{l}\text { Equal variances } \\
\text { not assumed }\end{array}\end{array}$ & & -12.190 & 29822. & 0.000 & -0.131 & 0.011 \\
\hline
\end{tabular}

Source: Authors' calculations based on EU-LFS data in 2017

As the data of Table 3 indicate that there are rather big differences in economic activity by gender in Latvia and the differences are statistically significant with very high probability (sig. 0.000).

In many scientific publications in many countries is concluded that there are differences in economic activity by age groups. To test this aspect, authors analysed results on economic activity by age groups. Main statistical indicators of economic activity in 2017 by age group in Latvia are included in Table 4. 
Table 4

Main statistical Indicators of Economic activity in 2017 by age group in Latvia

\begin{tabular}{|l|c|c|c|}
\hline Age group & Mean & N & Standard Deviation \\
\hline $15-24$ & 2.37 & 3499 & 0.895 \\
$25-34$ & 1.32 & 4322 & 0.677 \\
$35-44$ & 1.27 & 4905 & 0.616 \\
$45-54$ & 1.32 & 6088 & 0.684 \\
$55-64$ & 1.73 & 6490 & 0.929 \\
$65-74$ & 2.70 & 5141 & 0.709 \\
Total & 1.75 & 30445 & 0.938 \\
\hline
\end{tabular}

Source: Authors' calculations based on EU-LFS data in 2017

To make deeper analysis and be more precise in conclusions analysis of variance or ANOVA was used to test statistical hypotheses on differences of mean evaluations by respondent's age group on economic activity - results are included in Table 5.

Table 5

Analysis of Differences with ANOVA on economic activity in 2017 by age group in Latvia

\begin{tabular}{|l|c|r|r|r|c|}
\hline & Sum of Squares & \multicolumn{1}{|c|}{ df } & Mean Square & F & Sig. \\
\hline Between Groups & 9104.273 & 5 & 1820.855 & 3136.075 & 0.000 \\
Within Groups & 17673.363 & 30439 & 0.581 & & \\
Total & 26777.636 & 30444 & & & \\
\hline
\end{tabular}

Source: Authors' calculations based on EU-LFS data in 2017

As the data of Table 5 indicates there are differences in economic activity by age group in Latvia and they are statistically significant (sig. 0.000).

\section{CONCLUSIONS}

The analysis of the theoretical research showed that different aspects of employment is a problem during the last decades in many countries. Researchers focus on employment differences between male and female, education levels and urban/rural areas.

Unemployment rate shows that the highest unemployment is in Latvia, followed by Lithuania. At the same time unemployment rate in Estonia is the lowest and is below EU average level.

In case of regions of Latvia, the highest unemployment is in Latgale region where are also the most economically inactive people, but most economically active regions in Latvia is Pierīga and Riga region. 
In context of education level, in the most favourable position are people with higher education - the higher the level of education, the less likely it is to be unemployed in Latvia, economic inactivity is highly prevalent among people with basic education or lower, but the most unemployed people are with general secondary education.

There are differences in employment in Latvia by gender and they are statistically significant with very high probability or very low significance level (sig. 0.000).

\section{REFERENCES}

Bussemakers, C., Van Oosterhout, K., Kraaykamp, G., Spierings, N. (2017). Women's Worldwide Education-employment Connection: A Multilevel Analysis of the Moderating Impact of Economic, Political, and Cultural Contexts. World Development, 99, 28-41.

Cho, M.-J. Kim, E.-K. (2019). Subjective chewing ability and health-related quality of life among the elderly, Gerodontology, 36(2), 99-106.

Dogru, T., Mody, M., Suess, C., McGinley, S., Line, N. D. (2020). The Airbnb paradox: Positive employment effects in the hospitality industry. Tourism Management, 77, https://doi.org/10.1016/j.tourman.2019.104001.

Forster, A. G., Bol, T. (2018). Vocational education and employment over the life course using a new measure of occupational specificity. Social Science Research, 70, 176-197.

Forsyth, J. J., Jones, J., Duval, L., Bambridge, A. (2019). Opportunities and barriers that females face for study and employment in sport. Journal of Hospitality, Leisure, Sport \& Tourism Education, 24, 80-89.

Holtemöller, O., Pohle, F. (2019). Employment Effects of Introducing a Minimum Wage: The Case of Germany, Economic Modelling, https://doi.org/10.1016/ j.econmod.2019.10.006.

Muresan, I. C., Harun, R., Arion, F. H., Oroian, C. F., Dumitras, D. E., Mihai, V. C., Ilea, M., Chiciudean, D. I., Gliga, I. D., Chiciudean, G. O. (2019). Residents' perception of destination quality: Key factors for sustainable rural development, Sustainability, 11(9), Article number 2594.

NDPL 2014-2020 - National Development Plan of Latvia 2014-2020, available: https://likumi.lv/ta/id/253919-par-latvijas-nacionalo-attistibas-planu-20142020-gadam [viewed: 18.10.2019.]

Niedzwiedz, C. L., Thomson, K. H., Bambra, C., Pearce, J. R. Regional employment and individual worklessness during the Great Recession and the health of the workingage population: Cross-national analysis of 16 European countries, Social Science \& Medicine, https://doi.org/10.1016/j.socscimed.2019.112377.

Sumner, R. C., Bennett, R., Creaven, A.-M., Gallagher, S. Unemployment, employment precarity, and inflammation. Brain, Behaviour, and Immunity [in-press].

Wandner, S. A., Balducchi, D. E., O’Leary, C. J. (2018). Public Employment Policy for an Aging Workforce, Gerontology \& Geriatric Medicine, 4, 1-13.

Yamamoto, Y., Marsumoto, K., Kawata, K., Kaneko, S. (2019). Gender-based differences in employment opportunities and wage distribution in Nepal. Journal of Asian Economics, 64, 101131, https://doi.org/10.1016/j.asieco.2019.07.004. 
Wang, J. Li, Y., Long, D. (2019). Gender gap in entrepreneurial growth ambition: The role of culturally contingent perceptions of the institutional environment in China. International Journal of Entrepreneurial Behaviour and Research, 25(6), 1283-1307.

Zhu, L., Hao, Y., Lu, Z.-N., Wu, H. (2019). Do economic activities cause air pollution? Evidence from China's major cities. Sustainable Cities and Society, 49, 101593. 